Rev. Biol. Trop., 48(2/3): 353-360, 2000

www.ucr.ac.cr www.ots.ac.cr www.ots.duke.edu

\title{
Stomatopods (Crustacea: Hoplocarida) from the Gulf of Tehuantepec, Mexico
}

\author{
I. F., Barbosa-Ledesma, J. A. Gamboa-Contreras and J. A. Aké-Castillo \\ Departamento de Hidrobiología, Universidad Autónoma Metropolitana Unidad Iztapalapa, Apartado Postal 55-535. \\ México, Distrito Federal, C.P. 09340, México. FAX: (5) 7244738 \\ e-mail: fabarbos@mar.icmyl.unam.mx
}

Received 20-IV-1999. Corrected 17-III-2000. Accepted 23-III-2000.

\begin{abstract}
A total of 1173 specimens of Stomatopoda were captured in 27 localities at different depths (20 to 73 $\mathrm{m}$ ) during three oceanographic cruises in the Mexican Pacific along the continental shelf of the states of Oaxaca and Chiapas. Seven species were identified of the families Eurysquillidae, Lysiosquillidae and Squillidae. Squilla hancocki and Squilla parva were the most abundant species and the most frequently found together. The relationships between total length and carapace length were obtained for these species, which show that males of $S$. hancocki have a longer carapace length than females having the same total length, whereas for $S$. parva the opposite occurs. Larger sizes than previously reported were obtained for Lysiosquilla panamica and Squilla mantoidea. Squilla bigelowi was recorded for the first time in the Gulf of Tehuantepec. All the species were found in the intermediate platform (25-60 m); E. veleronis, $S$. hancocki and $S$. parva extended their distributions to the external platform (60-120 m), and $S$. hancocki and $S$. parva reached the circalittoral zone (10-25 m).
\end{abstract}

Key words: Stomatopoda, Crustacea, distribution, Gulf of Tehuantepec, Mexican Pacific.

The order Stomatopoda is an important component of the benthic fauna due to its high diversity and predatory behavior. Currently five superfamilies, 13 families, 70 genera and about 350 species are recognized, and the order is distributed world wide from tropical to temperate waters (Manning 1980, 1982, Hendrickx \& Salgado-Barragán 1991, Manning \& Camp 1993).

Although several studies related to the taxonomy, biology and distribution of stomatopods have been carried out along the Pacific Coast, most of them have been conducted in the Gulf of California and in the central part of the Mexican Pacific along the coasts of Nayarit, Jalisco, Colima, Michoacan and Guerrero (for a review of the literature see: Manning 1961,
Hendrickx 1990, Illescas-Monterroso et al. 1991, Hendrickx \& Salgado-Barragán 1994, Landa et al. 1997, Salgado-Barragán \& Hendrickx 1998, Arciniega 1998). The Gulf of Tehuantepec is one of the most productive zones of the tropical Mexican Pacific (Robles-Jarero \& Lara-Lara 1993) and only a few studies concerning stomatopods have been carried out in the area (Sosa et al. 1980, Hernández \& Villalobos 1984, Hendrickx \& SalgadoBarragán 1991, Hendrickx et al. 1997, Hendrickx \& Vázquez-Cureño 1998).

Some stomatopods are considered of commercial importance in several countries of Europe and Asia (Hendrickx \& SalgadoBarragán 1991, Hendrickx 1995a) and are fished accordingly. In Mexico these organisms 
are not used as a food source, even though they often form part of the by-catch of shrimp of the genera Farfantepenaeus and Litopenaeus (Rosales-Juárez 1976, Paul \& Hendrickx 1980, Chirichigno et al. 1982, Hendrickx 1985, Hendrickx \& Salgado-Barragán 1989, Robaina 1992, Hendrickx 1995b).

The aim of this work is to study the species composition of Stomatopoda communities from the Gulf of Tehuantepec and to determine the relationships between some morphometric parameters for the most abundant species.

\section{MATERIAL AND METHODS}

The Gulf of Tehuantepec is situated in southeastern Mexico, between $15^{\circ} 39^{\prime}$ and $14^{\circ}$ $33^{\prime} \mathrm{N}$ and between $96^{\circ} 31^{\prime}$ and $92^{\circ} 16^{\prime} \mathrm{W}$. This region is characterized by a dry (from November to April) and a rainy season (from May to October). From December to February, winds blowing from the Gulf of Mexico across the Isthmus of Tehuantepec (known as "Tehuanos") are responsible for upwellings in the Gulf of Tehuantepec. Nutriment enriched waters enhance the growth of some commercial species (Roden 1961, Stumpf 1975, Molina-Cruz \&Martínez-López 1994, Hendrickx 1995b).

Specimens reported herein were collected in 1989 during three different oceanographic cruises aboard the R/V "El Puma" of the Universidad Nacional Autónoma de México: January (OPC-GTl), May (MIMAR-V) and November (FIQUIMBI-I) (Fig. 1). A total of 51 stations located on the continental shelf were sampled along transects perpendicular to the coast. Organisms were caught with a commercial shrimp trawl (mesh width, 4.44 $\mathrm{cm}$ ) operating during 30 minutes. Specimens were fixed on board with formaldehyde $(8 \%)$ and later rinsed with freshwater and preserved in $70 \%$ ethyl alcohol.

Identifications were based upon Hendrickx and Salgado-Barragán (1991); males (M) and females (F) were separated for each species and each sampling station (Stn).
Total length (TL: from rostrum to telson) was measured for all specimens and carapace length (CL: length along the median carina) for some. Measurements were made using a vernier and a stereoscopic microscope with a millimetric grid for organisms smaller than 50 $\mathrm{mm}$ TL. Correlation coefficients for morphometric relationships between TL and CL (Curts 1984) were calculated for the most abundant species.

In this paper we provide the following information for the examined material: the name of cruise, sampling station, date, number of specimens, sex, range of total length and sampling depth. We include comments about the distribution and associations of the species.

The specimens are deposited in the Stomatopod Collection at the Laboratorio de Ictiología y Ecología Costera, Universidad Autónoma Metropolitana Iztapalapa, Mexico.

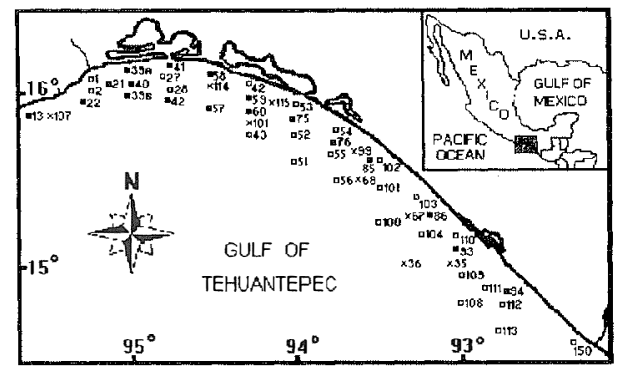

Fig. 1. Location of sampling stations of OPC-GT1 (X), MIMAR-V ( $\square$ ) and FIQUIMBI-I (圆) cruises

\section{RESULTS}

\section{Family Eurysquillidae \\ Manning, 1977}

Eurysquilla veleronis (Schmitt, 1940)

Material Examined: MIMAR-V:Sin 54, 7/V/89, 3 F (TL 13.67-15.54 mm), $31 \mathrm{~m}$; Stn $101,9 / \mathrm{V} / 89,1 \mathrm{M}$ (TL $24.23 \mathrm{~mm}$ ) and $1 \mathrm{~F}$ (TL $20.07 \mathrm{~mm}$ ), $37 \mathrm{~m}$. FIQUIMBI-I: Stn 13, 12/XI/89, 3 F (TL 13.83-26.98 mm), $73 \mathrm{~m}$; Stn 39A, 13/XI/89, $1 \mathrm{M}$ (TL $22.56 \mathrm{~mm}$ ), $50 \mathrm{~m}$. 
Distribution: This species has been reported from the Gulf of California to the Gulf of Panama (Manning 1974, Hendrickx 1984, Salgado-Barragán 1986, Hendrickx \& SalgadoBarragán 1991, Vargas et al. 1996, Landa et al. 1997, Vargas \& Cortés 1997, Arciniega 1998) between 29 and $118 \mathrm{~m}$ (Hendrickx \& SalgadoBarragán 1989).

Comments: This species was collected with $S$. hancocki in one station and with $S$. hancocki and $S$. parva in two stations.

\section{Family Lysiosquillidae Giesbrecht, 1910}

\section{Lysiosquilla panamica Manning, 1971}

Material Examined: MIMAR-V: Stn 108, $10 / \mathrm{V} / 89,1 \mathrm{~F}$ (TL $26.88 \mathrm{~mm}$ ), $56 \mathrm{~m}$. FIQUIMBII: Stn 39B, 13/XI/89, 3 M (TL 22.15-23.92 mm) and $1 \mathrm{~F}$ (TL $22.77 \mathrm{~mm}$ ), $50 \mathrm{~m}$; Stn 59, 14/XI/89, $1 \mathrm{M}$ (TL $212.7 \mathrm{~mm}$ ), $28 \mathrm{~m}$.

Distribution: Offshore, from Nayarit to Guerrero and in the Gulf of Tehuantepec, Mexico (Salgado-Barragán \& IllescasMonterroso 1987, Hendrickx \& SalgadoBarragán 1991, Illescas-Monterroso et al. 1991, Hendrickx et al. 1997, Landa \& Arciniega 1997, Landa et al. 1997, Arciniega 1998), in the Gulf of Panama and Ecuador (Hendrickx \& SalgadoBarragán 1991), at depths from 3 to $90 \mathrm{~m}$ (Hendrickx \& Salgado-Barragán 1989).

Comments: This species was collected with $S$. mantoidea in one station; with S. bigelowi, $S$. hancocki and S. parva in one station; with $S$. hancocki, S. panamensis and S. parva in one station.

\section{Family Squillidae Latreille, 1803}

\section{Squilla bigelowi Schmitt, 1940}

Material Examined: MIMAR-V: Stn 108, 10/V/89, $3 \mathrm{M}$ (TL 24.54-27.61 mm) and $10 \mathrm{~F}$ (TL 19.03-30.36 mm), $56 \mathrm{~m}$.

Distribution: Gulf of California (SalgadoBarragán 1986, Hendrickx \& SalgadoBarragán 1991) and the coast of Nayarit (Schmitt 1940), Mexico; off the coast of Costa Rica (Boone 1930), at depths between 6 and 150 m (Hendrickx \& Salgado-Barragán 1989,
1991). This first recorded finding of the species in the Gulf of Tehuantepec, especially since there were found both males and females in the samples, suggests that there might be an established population there.

Comments: This species was found in only one station with $S$. panamensis, S. hancocki and $L$. panamica.

\section{Squilla hancocki Schmitt, 1940}

Material Examined: OPC-GT1: Stn 114, 12/I/89, $4 \mathrm{M}$ (TL 74.9-88.47 mm) and $1 \mathrm{~F}$ (TL $34.06 \mathrm{~mm}$ ), $28 \mathrm{~m}$; Stn 115, 13/I/89, $4 \mathrm{M}$ (TL 21.26-73.85 mm), $33 \mathrm{~m}$. MIMAR-V: Stn 1, 2/V/89, $28 \mathrm{M}$ (TL 24.54-46.85 mm) and 30 F (TL 24.07-52.41 mm), $45.3 \mathrm{~m}$; Stn 28, 12/V/89, $47 \mathrm{M}$ (TL 24.02-47.06 mm) and 44 F (TL 25.58$44.46 \mathrm{~mm}$ ), $60 \mathrm{~m}$; Stn 51, 6/V/89, $41 \mathrm{M}$ (TL 25.53-67.39 mm) and 40 F (TL 27.76-55.9 mm), $64 \mathrm{~m}$; Stn 52, 7/V/89, 4 M (TL 45.44-87.13 mm) and $4 \mathrm{~F}$ (TL 26.78-37.75 mm), $35 \mathrm{~m}$; Stn 54, 7/V/89, $103 \mathrm{M}$ (TL 28.28-47.42 mm) and $96 \mathrm{~F}$ (TL 19.08-61.83 mm), $31 \mathrm{~m}$; Stn 101, 9/V/89, 16 M (TL 30.84-70.92 mm) and 28 F (TL 29.84$76.49 \mathrm{~mm}$ ), $37 \mathrm{~m}$; Stn 102, 9/V/89, 1 F (TL 60 $\mathrm{mm}$ ), $21 \mathrm{~m}$; Stn 104, 10/V/89, $20 \mathrm{M}$ (TL 28.28$40.71 \mathrm{~mm}$ ) and $32 \mathrm{~F}$ (TL 27.14-40.71 mm), 48 m; Stn 108, 10/V/89, $135 \mathrm{M}$ (TL 21.37-76.75 $\mathrm{mm}$ ) and $163 \mathrm{~F}$ (TL 23.03-60.68 mm), $56 \mathrm{~m}$; Stn $109,10 / \mathrm{V} / 89,33 \mathrm{M}$ (TL 18.56-55.27 mm) and $21 \mathrm{~F}$ (TL 25.58-52.05 mm), $45 \mathrm{~m}$; Stn 110 , $10 / \mathrm{V} / 89,1 \mathrm{M}$ (TL $18.66 \mathrm{~mm}$ ) and $1 \mathrm{~F}$ (TL 20.07 $\mathrm{mm}$ ), $25 \mathrm{~m}$; Stn 112, 11/V/89, $8 \mathrm{M}$ (TL 36.66$59.69 \mathrm{~mm}$ ) and $9 \mathrm{~F}$ (TL 39-82.68 mm), $40 \mathrm{~m}$; Stn $113,11 / \mathrm{V} / 89,5 \mathrm{M}$ (TL 26.2-31.4 mm) and 8 F (TL 27.14-71.7 mm), 67.5 m. FIQUIMBI-I: Stn 13, 12/XI/89, 2 M (TL 29.64-30.68 mm) and $5 \mathrm{~F}$ (TL 22.36-34.32 mm), $73 \mathrm{~m}$; Stn 39B, 13/XI/89, $16 \mathrm{M}$ (TL 18.25-37.2 mm) and $12 \mathrm{~F}$ (TL 17.42-53.45 mm), $50 \mathrm{~m}$; Stn 42, 13/XI/89, 4 $\mathrm{M}$ (TL 66.19-70.82 $\mathrm{mm}$ ) and $4 \mathrm{~F}$ (TL 55.32$75.97 \mathrm{~mm}), 51 \mathrm{~m}$.

Morphometric relationships: The best correlation coefficient was obtained for a linear model, indicating that for each unit of TL, CL increases 0.212 for males (t-Student $\mathrm{p}<.2471$ ) and 0.207 for females (t-Student $\mathrm{p}<$ 6091) (Fig. 2). 
Distribution: From Sinaloa, Mexico to Paita, Peru (Manning 1972, Reaka \& Manning 1980, Hendrickx \& van der Heiden 1983a, 1983b, Hendrickx 1984, Hernández \& Villalobos 1984, Hendrickx \& Salgado-Barragán 1991, Landa et al. 1997, Vargas \& Cortés 1997, Arciniega 1998), at depths between 29 and $220 \mathrm{~m}$ (Hendrickx \& Salgado-Barragán 1989, 1991).

Comments: $S$. hancocki was collected with $S$. parva in eight stations; with $S$. panamensis and $E$. veleronis in one stationwith each one; with $S$. mantoidea and S. parva in one station; with E. veleronis and $S$. parva in two stations; with $L$. panamica, S. bigelowi and S. panamensis in one station, and L. panamica, S. panamensis and $S$. parva in one station.

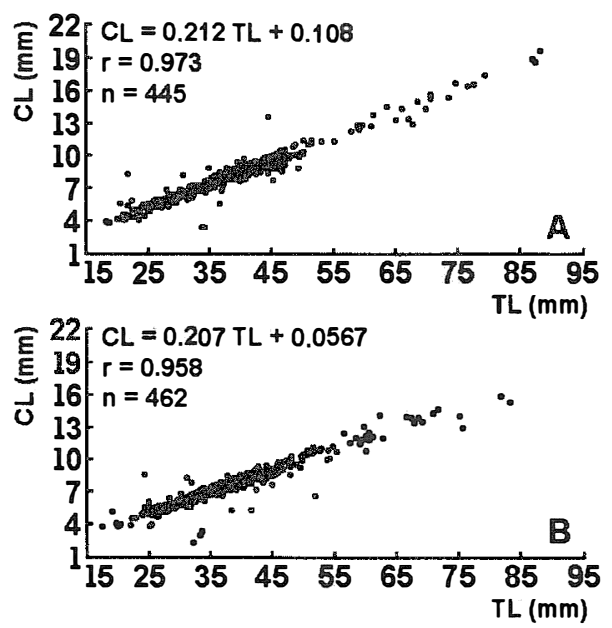

Fig. 2. Total length (TL) - carapace length (CL) relationship for males (A) and females (B) of Squilla hancocki.

\section{Squilla mantoidea Bigelow, 1893}

Material Examined: MIMAR-V: Stn 103, 9/V/89, $1 \mathrm{M}$ (TL 207.4 mm) and $1 \mathrm{~F}$ (TL 192.1 mm), 27 m; Stn 110, 10/v/89, 1 M (TL 104.6 $\mathrm{mm}$ ), $25 \mathrm{~m}$; Stn 111, 10/V/89, $1 \mathrm{M}$ (TL 160.6 mm), 25 m. FIQUIMBI-I: Stn 59, 14/XI/89, 1 M (TL 159 mm), 28 m; Stn 85, 19/XI/89, 1 M (TL $159 \mathrm{~mm}$ ) and $1 \mathrm{~F}$ (TL $151.1 \mathrm{~mm}$ ), $25 \mathrm{~m}$; Stn 86, 20/XI/89, 1 F (TL 48.2 mm), 26 m.

Distribution: From Sonora, Mexico, to Tumbes, Peru (Hernández \& Villalobos 1984, Salgado-Barragán 1986, Hendrickx \& Salgado-
Barragán 1991, Vargas et al. 1996, Landa et al. 1997, Arciniega 1998), at depths between 4 and 60 m (Hendrickx \& Salgado-Barragán 1989, Illescas-Monterroso et al. 1991).

Comments: This species was collected with $S$. parva in two stations; with L. panamica in one station; with $S$. hancocki and $S$. parva in one station.

Squilla panamensis Bigelow, 1891

Material Examined: MIMAR-V: Stn 1, 2/V/89, $2 \mathrm{M}$ (TL 70.42-89 mm) and $2 \mathrm{~F}$ (TL 58.53-72.59 mm), $45.3 \mathrm{~m}$; Stn 108, 10/V/89, 1 M (TL $36.5 \mathrm{~mm}$ ), $56 \mathrm{~m}$. FIQUIMBI-I: Stn 39B, 13/XI/89, $1 \mathrm{M}$ (TL $35.93 \mathrm{~mm}$ ) and $3 \mathrm{~F}$ (TL 56.68-73.64 mm), $50 \mathrm{~m}$.

Distribution: From Guaymas Bay, Mexico, to Tumbes; Peru (Hernández \& Villalobos 1984, Hendrickx \& Salgado-Barragán 1991, IllescasMonterroso et al. 1991, Castro \& Vargas 1996, Vargas et al. 1996, Landa et al. 1997, Vargas \& Cortés 1997, Arciniega 1998), at depths from 18 to 110 m (Hendrickx \& Salgado-Barragán 1989, 1991).

Comments: The species was found with $S$. hancocki in one station; with L. panamica, $S$. bigelowi and $S$. hancocki in one station; and with $L$. panamica, S. hancocki and S. parva in one station.

Squilla parva Bigelow, 1891

Material Examined: OPC-GT1: Stn 114, $12 / \mathrm{/} / 89,4 \mathrm{M}$ (TL $40.05-49.14 \mathrm{~mm}$ ) and $3 \mathrm{~F}$ (TL 23.4-39.46 mm), $28 \mathrm{~m}$; Stn 115, 13/1/89, $1 \mathrm{M}$ (TL $24.54 \mathrm{~mm}$ ), $33 \mathrm{~m}$. MIMAR-V: Stn 28, 12/V/89, $1 \mathrm{M}$ (TL $57.87 \mathrm{~mm}$ ) and $1 \mathrm{~F}$ (TL 55.74 $\mathrm{mm}$ ), $60 \mathrm{~m}$; Stn 51, 6/V/89, 2 F (TL 32.91-52.41 $\mathrm{mm}$ ), $64 \mathrm{~m}$; Stn 53, 7/V/89, $1 \mathrm{M}$ (TL $49.5 \mathrm{~mm}$ ), 37 m; Stn 101, 9/V/89, 3 M (TL 27.45-53.24 $\mathrm{mm}$ ) and $1 \mathrm{~F}$ (TL $19.86 \mathrm{~mm}$ ), $37 \mathrm{~m}$; Stn 103, 9/V/89, $9 \mathrm{M}$ (TL 34.37-59.64 mm) and 5 F (TL 46.9-59.74 mm), $27 \mathrm{~m}$; Stn 104, 10/v/89, $1 \mathrm{~F}$ (TL $31.04 \mathrm{~mm}$ ), $48 \mathrm{~m}$; Stn 109, 10/V/89, $7 \mathrm{M}$ (TL 15.8-38.27 mm) and 3 F (TL 25.94-36.29 $\mathrm{mm}$ ), $45 \mathrm{~m}$; Stn 110, 10/V/89, $19 \mathrm{M}$ (TL 32.39$57.04 \mathrm{~mm}$ ) and $32 \mathrm{~F}$ (TL 43.16-59.69 mm), 25 $\mathrm{m} ; \mathrm{Stn} 111,10 / \mathrm{V} / 89,19 \mathrm{M}$ (TL 19.5-64.48 mm) and $25 \mathrm{~F}$ (TL 48.56-70.09 mm), $25 \mathrm{~m}$; Stn 112, 
11/V/89, $5 \mathrm{M}$ (TL 35.15-57.56 mm) and $7 \mathrm{~F}$ (TL 28.91-55.58 mm), $40 \mathrm{~m}$; Stn 113, 11/V/89, $1 \mathrm{M}$ (TL $29.17 \mathrm{~mm}$ ), $67.5 \mathrm{~m}$. FIQUIMBI-I: Stn 13, 12/XI/89, $1 \mathrm{M}$ (TL $23.19 \mathrm{~mm}$ ), $73 \mathrm{~m}$; Stn 39B, 13/XI/89, 1 F (TL $30.68 \mathrm{~mm}$ ), $50 \mathrm{~m}$; Stn 93, 20/XI/89, $3 \mathrm{M}$ (TL 29.27-47 mm) and $2 \mathrm{~F}$ (TL 53.35-55.64 mm), $26 \mathrm{~m}$; Stn 94, 20/XI/89, $1 \mathrm{~F}$ (TL $55.79 \mathrm{~mm}$ ), $20 \mathrm{~m}$.

Morphometric relationships: The best correlation coefficient was obtained for a linear model, indicating that for each unit of TL, CL increases 0.207 for males (t-Student $\mathrm{p}<.4905$ ) and 0.215 for females (t-Student $\mathrm{p}<$ .6572) (Fig. 3).

Distribution: Topolobampo Bay, Mexico, to Tumbes, Peru (Hernández \& Villalobos 1984, Hendrickx \& Salgado-Barragán 1991, Vargas et al. 1996, Landa et al. 1997, Arciniega 1998), commonly reported at depths from 7 to 80 m (Hendrickx \& Salgado-Barragán 1989, 1991). Schmitt (1940) found this species at a depth of $214 \mathrm{~m}$.

Comments: $S$. parva was collected with $S$. hancocki in eight stations; with $S$. mantoidea in two stations; with $E$. veleronis and $S$. hancocki in two stations; with $S$. hancocki and $S$. mantoidea in one station; with $L$. panamica, S. hancocki and S. panamensis in one station.

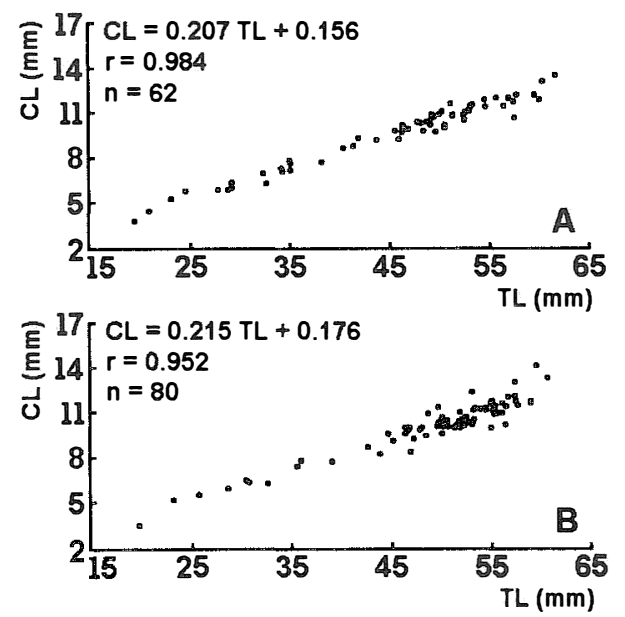

Fig. 3. Total length (TL) - carapace length (CL) relationship for males (A) and females (B) of Squilla parva.

\section{DISCUSSION}

Species composition: A total of 1173 specimens were captured, belonging to seven species: Eurysquilla veleronis (2 M, $7 \mathrm{~F})$, Lysiosquilla panamica (4 M, 2 F), Squilla bigelowi (3 M, 10 F), Squilla hancocki (471 M, 499 F), Squilla mantoidea (5 M, 3 F), Squilla panamensis (4 M, $5 \mathrm{~F}$ ) and Squilla parva (74 M, $84 \mathrm{~F})$.

The largest number of specimens was collected (1 088) during the oceanographic cruise MIMAR-V in the rainy season and the smallest (17) during the oceanographic cruise OPC-GT1 in the dry season. The number of specimens captured per species and station was variable (Table 1). The genus Squilla represented $98.72 \%$ of the total, $S$. hancocki was the most abundant species in the three cruises, followed by $S$. parva, thus indicating that both species are well established in the Gulf of Tehuantepec. Eurysquilla veleronis, $L$. panamica, S. mantoidea and S. panamensis were captured only in the oceanographic cruises MIMAR-V and FIQUIMBI-I (rainy and dry seasons) whereas $S$. bigelowi was captured only in the oceanographic cruise MIMAR-V (rainy season), in one station.

TABLE 1

Specimens of stomatopods collected from the Gulf of Tehuantepec (males and females) and number of sampling station

$\begin{array}{lccc}\text { Species } & \text { Males } & \text { Females } & \text { Stations } \\ \text { Eurysquilla veleronis } & 2 & 7 & 4 \\ \text { Lysiosquilla panamica } & 4 & 2 & 3 \\ \text { Squilla bigelowi } & 3 & 10 & 1 \\ \text { Sqilla hancocki } & 471 & 499 & 18 \\ \text { Sqilla mantoidea } & 5 & 3 & 6 \\ \text { Squilla panamensis } & 4 & 5 & 3 \\ \text { Squilla parva } & 74 & 84 & 17\end{array}$

Association of species: Stomatopods were caught in 27 out of 51 trawls. Species which were found alone are: E. veleronis, $S$ hancocki, S. mantoidea and S. parva, mainly during the cruise FIQUIMBI-I (dry season), whereas L. panamica, S. bigelowi and $S$. panamensis were found in association with 
other species. Associations of two species were found in 15 stations, most commonly during the MIMAR-V cruise (rainy season). The species most frequently found together were $S$. hancocki and $S$. parva (eight stations). Associations among three species were found in three stations: S. hancocki, S. parva and $E$. veleronis (Stn 101 MIMAR-V); S. hancocki, S. parva and $S$. mantoidea (Stn 110 MIMAR-V); E. veleronis, S. hancocki and $S$. parva $(\operatorname{Stn} 13$ FIQUIMBI-I). Only in two stations were four species found together: $L$. panamica, $S$. bigelowi, $S$. hancocki and $S$. panamensis (Stn 108 MIMAR-V); L. panamica, S. hancocki, S. panamensis and $S$. parva (Stn 39B FIQUIMBI-I).

Squilla hancocki and $S$. parva were the species most frequently found together (12) and were abundant in the sampling area. Their wide distribution along the continental shelf, between 20 and $73 \mathrm{~m}$, could indicate that they are representative of the zone, unlike the report by Hendrickx and Salgado-Barragán (1991) for the Gulf of California.

Morphometric data: TL and CL values obtained for most species agree well with those related in previous studies (Hendrickx \& Salgado-Barragán 1991). The exceptions are $L$. panamica and $S$. mantoidea in which larger sizes were measured (male specimens, TL of 212.7 and $207.4 \mathrm{~mm}$ respectively).

The best correlation coefficient calculated for $S$. hancocki and S. parva corresponded, in both cases, to a linear regression. The models show that males of $S$. hancocki have a longer CL than females having the same TL, whereas for $S$. parva the opposite occurs.

There is no fishery for stomatopods in Mexico, although Hendrickx (1985) has pointed out that some species inhabiting the Gulf of California could be commercialized. A similar situation seems to occur in the Gulf of Tehuantepec, where $S$. hancocki and $S$. parva seem to be abundant, and large specimens of $S$. mantoidea and $L$. panamica can be found.

Bathymetric analysis: The specimens collected in this study were obtained at depths between 20 and $73 \mathrm{~m}$. Squilla hancocki was collected at a depth of $21 \mathrm{~m}$, thus extending the lower bathymetric limit previously reported. The largest number of organisms was collected between 25-56 $\mathrm{m}$ during the rainy season, and the depth of co-ocurrence of the largest number of species (four) was between 50-56 m.

Following Hendrickx \& SalgadoBarragán (1991), the species of stomatopods in the Gulf of Tehuantepec can be classified as follows: all the species were found in the intermediate platform $(25-60 \mathrm{~m}) ;$ E. veleronis, $S$. hancocki and $S$. parva extended their distribution to the external platform (60-120 $\mathrm{m})$; $S$. hancocki and $S$. parva reached the circalittoral zone (10-25 m).

\section{AKNOWLEDGEMENTS}

We express our gratitude to Michel E. Hendrickx for his comments and corrections and to Francisco Solís for making important suggestions to an early manuscript. Two anonymous reviewers improved the manuscript. Michael Roach checked the English.

\section{RESUMEN}

Se capturaron un total de 1173 especímenes del orden Stomatopoda en 27 localidades a diferentes profundidades (20 a $73 \mathrm{~m}$ ) durante tres cruceros oceanográficos en el Pacífico mexicano a lo largo de la plataforma continental de los estados de Oaxaca y Chiapas. Se identificaron siete especies de las familias Eurysquillidae, Lysiosquillidae y Squillidae. Squilla hancocki y Squilla parva fueron las especies más abundantes y las más frecuentemente encontradas juntas. Se obtuvieron las relaciones entre la longitud total y la longitud del caparazón para estas dos especies; que indican que con una misma longitud total los machos de $S$. hancocki tienen una longitud del caparazón mayor que las hembras, mientras que para $S$. parva sucede lo contrario. Se registraron longitudes totales más grandes a las reportadas previamente para Lysiosquilla panamica y Squilla mantoidea. Squilla bigelowi se registró por primera vez en el área. Todas las especies se encontraron en la plataforma intermerdia (25-60 m); E. Veleronis, S. Hancocki y S. parva se distribuyeron hasta la plataforma externa $(60-120 \mathrm{~m})$ y $S$. hancocki y $S$. parva abarcaron la zona circalitoral (10-25 m). 


\section{REFERENCES}

Arciniega, F. J. 1998. Distribución y abundancia de los crustáceos estomatópodos de fondos blandos en las costas de Jalisco y Colima, México. Cienc. Mar. 24: 169-181.

Boone, L. 1930. Crustacea: Stomatopoda and Brachyura. Scientific Results of the Cruises of the Yachts "Eagle" and "Ara", 1921-1928, Wm. K. Vanderbilt, Commanding. Bull. Vanderbilt Mar. Mus. 2: 1-228.

Castro, M. V. \& R. C. Vargas. 1996. Annotated list of species of marine crustaceans (Decapoda and Stomatopoda) from Golfo Dulce, Costa Rica. Rev. Biol. Trop. 44 (Suppl. 3): 87-95.

Chirichigno, P. N., W. Fisher \& C. E. Nauen. 1982. INFOPESCA. Catálogo de especies marinas de interés económico actual o potencial para América Latina. Parte 2. Pacífico Central y Sur-oriental, Roma, FAO/PNUD, SIC82/2: $588 \mathrm{p}$.

Curts, J. B. 1984. Introducción al análisis de residuos en biología. Biotica 9: 271-278.

Hendrickx, M. E. 1984. Distribution and abundance of stomatopods (Crustacea, Hoplocarida) in southern Sinaloa, Mexico. Rev. Biol. Trop. 32: 269-277.

Hendrickx, M. E. 1985. Diversidad de los macroinvertebrados bentónicos acompañantes del camarón en el área del Golfo de California y su importancia como recurso potencial, Cap. 4: 95-148. In: Yañez-Arancibia, A. (ed.). Recursos pesqueros potenciales de México: La pesca acompañante del camarón. Prog. Univ. de Alimentos, Pesca, Universidad Nacional Autónoma de México. México D. F.

Hendrickx, M. E. 1990. The stomatopod and decapod crustaceans collected during the GUAYTEC II Cruise in the Central Gulf of California, Mexico, with the description of a new species of Plesionika Bate (Caridea: Pandalidae). Rev. Biol. Trop. 38: 35-53.

Hendrickx, M. E. 1995a. Estomatópodos, p. 355-382. In: W. Fischer, F. Krupp, W. Schneider, C. Sommer, K. E. Carpenter \& V. H. Niem (eds.). Guía para la identificación de especies para los fines de la pesca. Pacífico centro-oriental. Vol. 1. Plantas e invertebrados. FAO, Roma.

Hendrickx, M. E. 1995b. Introducción, p. 1-7. In: W. Fischer, F. Krupp, W. Schneider, C. Sommer, K. E. Carpenter \& V. H. Niem (eds.). Guía para la identificación de especies para los fines de la pesca. Pacífico centrooriental. Plantas e invertebrados. FAO, Roma.
Hendrickx, M. E. \& J. Salgado-Barragán. 1989. Ecology and fishery of stomatopods in the Gulf of California, p. 241-249. In: E. A. Ferrero (ed.). Biology of Stomatopods. Mucchi, Modena.

Hendrickx, M. E. \& J. Salgado-Barragán. 1991. Los estomatópodos (Crustacea: Hoplocarida) del Pacífico Mexicano. Inst. Cienc. del Mar y Limnol. Univ. Nal. Autón. México Publ. Esp. 10: 1-200.

Hendrickx, M. E. \& J. Salgado-Barragán. 1994. Stomatopods (Crustacea: Hoplocarida) collected off the coasts of Sinaloa, Mexico, during the BIOCAPESS Cruises IV, V and VI (August 1991, March and June 1992). An. Inst. Biol. Univ. Nac. Autón. México 65: 217-231.

Hendrickx, M. E. \& A. M. van der Heiden. 1983a. Four species of Stomatopoda and Decapoda Brachyura new to the marine fauna of the Gulf of California, Mexico. Crustaceana 44: 109-110.

Hendrickx, M. E. \& A. M. van der Heiden. 1983b. New records of stomatopod and decapod Crustacea along the Pacific coast of America. Bull. So. Calif. Acad. Sci. 83: 110-112.

Hendrickx, M. E. \& L. A. Vázquez-Cureño. 1998. Composition and zoogeographical affinities of the stomatopod and decapod crustacean fauna collected during the CEEMEX P4 cruise in the Gulf of Tehuantepec, Mexico. Bull. Inst. R. Sci. Nat. Belg., Biol. 68: 135-144.

Hendrickx, M. E., M. Demestre, A. Esparza-Haro \& J. Salgado-Barragán. 1997. Stomatopod and decapod crustaceans collected during the CEEMEX P5 and CEEMEX P7 cruises to the Gulf of Tehuantepec, Mexico. Oceanides 11: 1-28.

Hernández, A. J. \& J. L. Villalobos. 1984. Estudio preliminar de la fauna de crustáceos decápodos y estomatópodos del Golfo de Tehuantepec. Tesis de Licenciatura. Universidad Nacional Autónoma de México. México. 148 p.

Illescas-Monterroso, C. M., J. Salgado-Barragán \& J. L. Villalobos. 1991. Distribución geográfica, batimétrica y aspectos ecológicos de los estomatópodos recolectados durante las campañas oceanográficas DAMA y ATLAS en la plataforma continental de Nayarit, Michoacán y Guerrero, México. An. Inst. Biol. Univ. Autón. México, Ser. Zool. 62: 431-451.

Landa, J. V. \& J. Arciniega. 1997. Ampliación de ámbito de Lysiosquilla panamica (Stomatopoda: Lysiosquillidae) en el Pacífico tropical mexicano. Rev. Biol. Trop. 45: 1269-1270. 
Landa, J. V., J. Arciniega, R. García de Quevedo, J. E. Michel \& G. González. 1997. Crustáceos decápodos y estomatópodos de fondos blandos de la plataforma continental de Jalisco y Colima, México. Cienc. Mar. 23: 4.3-417.

Manning, R. B. 1961. A new Lysiosquilla (Crustacea: Stomatopoda) from the Gulf of California, with a redescription of $L$. decemspinosa Rathbun. Proc. Biol. Soc. Wash. 74: 29-35.

Manning, R. B. 1972. Notes on some stomatopod crustaceans from Peru. Proc. Biol. Soc. Wash. 85: 297-307.

Manning, R. B. 1974. Stomatopods collected by Th. Mortensen in the eastern Pacific Region (Crustacea: Stomatopoda). Steenstrupia 3: 101-109.

Manning, R. B. 1980. The superfamilies, families and genera of recent stomatopod Crustacea with diagnoses of six new families. Proc. Biol. Soc. Wash. 93: $362-372$

Manning, R. B. 1982. Hoplocarida, p. 237-241. In: S. P. Parker (ed.). Synopsis and Classification of Living Organisms. McGraw-Hill, New York.

Manning, R. B. \& D. K. Camp. 1993. Erythrosquilloidea, a new superfamily, and Tetrasquillidae, a new family of stomatopod crustaceans. Proc. Biol. Soc. Wash. 106: 85-91.

Molina-Cruz, A. \& M. Martínez-López. 1994. Oceanography of the Gulf of Tehuantepec, Mexico, indicated by Radiolaria remains. Palaeogeogr. Palaeoclimatol. Palaeoecol. 110: 179-195

Paul, R. K. \& M. E. Hendrickx. 1980. Crustaceans in the shrimp by catch of the coast of Sinaloa and Nayarit. Bull. So. Calif. Acad. Sci. 79: 109-111.

Reaka, M. I. \& R. B. Manning. 1980. The distributional ecology and zoogeographycal relationships of shallow water stomatopod Crustacea from Pacific Costa Rica. Smithson. Contr. Mar. Sci. 7: 1-29.

Robaina, G. 1992. Galeras (Estomatópodos), p. 103-105. In: F. Cervigón, R. Cipriani, W. Fischer, L. Garibaldi, M. E. Hendrickx, A. J. Lemus, R. Marquéz, J. M. Poutiers, G. Robaina \& B. Rodríguez (eds.). Fichas FAO de identificación de especies para los fines de pesca. Guía de campo de las especies marinas y de aguas salobres de la Costa Septentrional de Sur América. FAO, Roma.
Robles-Jarero, E. G. \& J. R. Lara-Lara. 1993. Phytoplankton productivity in the Gulf of Tehuantepec. J. Plank. Res. 15: $1341-1358$

Roden, G. I. 1961. Sobre la circulación producida por el viento en el Golfo de Tehuantepec y sus efectos sobre las temperaturas superficiales (On the wind driven circulation in the Gulf of Tehuantepec and its effect upon surface temperatures). Geofis. Int. 1: 55-76.

Rosales-Juárez, F. 1976. Contribución al conocimiento de la fauna de acompañamiento del camarón de alta mar, frente a la costa de Sinaloa, México, p. 25-80. In: Inst. Nal. de Pesca (ed.). Recursos de la pesca costera en México, Veracruz. México.

Salgado-Barragán, J. 1986. Contribución al estudio de los estomatópodos del Golfo de California, taxonomía y distribución de las especies (Crustacea: Hoplocarida). Tesis de Licenciatura. Universidad Nacional Autónoma de México. México. 167 p.

Salgado-Barragán, J. \& M. E. Hendrickx. 1998. A new species of Nannosquilla (Crustacea: Stomatopoda: Nannonquillidae) from the eastern Pacific and new records of species of Neogonodactylus (Gonodactylidae) from the Pacific coast of Mexico. Proc. Biol. Soc. Wash. 111: 43-51.

Salgado-Barragán, J. \& C. Illescas-Monterroso. 1987. First record of Lysiosquilla panamica Manning, 1971 (Crustacea: Stomatopoda) in the Pacific waters of Mexico. Rev. Biol. Trop. 35: 159-160.

Schmitt, W. L. 1940. The stomatopods of the west coast of America based on collections made by the Allan Hancock Expedition, 1933-1938. Allan Hancock Found. Pac. Exped. 5: 129-225.

Sosa, P., J. L. Hernández \& J. L. Villalobos. 1980. Estudio prospectivo de los crustáceos (Decapoda y Stomatopoda) del Golfo de Tehuantepec, México. Sec. Mar. Dir. Gral. Ocean. B-80-10: 1-50.

Stumpf, G. H. 1975. Satellite detection of upwelling in the Gulf of Tehuantepec, Mexico. J. Phys. Oceanogr. 5: 383-388.

Vargas, R. \& J. Cortés. 1997. Biodiversidad marina de Costa Rica: Orden Stomatopoda (Crustacea: Hoplocarida). Rev. Biol. Trop. 45: 1531-1539.

Vargas, R., S. Jesse \& M. Castro. 1996. Checklist of crustaceans (Decapoda and Stomatopoda), collected during the Victor Hensen Costa Rica Expedition (1993/1994). Rev. Biol. Trop. 44: 97-102. 